\title{
Charter Roadblocks to Defence Disclosure
}

\section{ANNE STALKer ${ }^{*}$}

This article examines the issue of compelled defence disclosure in light of the framework for discovery set out in Stinchcombe v. The Queen and s. 7 of the Charter. The author contends that the introduction of compelled defence disclosure into the Canadian criminal law system would be inappropriate given the current s. 7 Charter analysis.

The principles of Crown disclosure gleaned from Stinchcombe and current rationales for imposing obligations of disclosure on the defence are reviewed. The impact upon the accused's right to silence, right to make full answer and defence, and the right against self-incrimination. is used 10 illustrate the inadequacies of the current justifications for compelled defence disclosure. The author concludes that while incremental expansion of particular existing defence obligations to disclose may be appropriate. it appears that the constitutional barriers to implementing full reciprocal defence disclosure in Canada are complete and just.
Cet article examine la question de l'obligation de divulguer par la défense à la lumière de la démarche de la communication préalable, établie dans l'affaire Stinchcombe $c$. La Reine et l'article 7 de la Charte. L'auteur estime que, compte tenu de l'analyse actuelle de l'article 7 de la Charte, il ne serait pas approprié d'introduire la divulgation obligatoire de la part de la défense dans le système de droit criminel canadien.

On y revoil les principes de la divulgation par la Couronne provenant de l'affaire Stinchcombe et des motifs actuels imposant la communication par la défense. Les conséquences de cette divulgation sur le droit au silence de l'accusé, sur son droit de présenter une défense pleine et entière et sur son droit de ne pas s'incriminer servent à illustrer les faiblesses des motifs actuels de celte obligation. L'auteur conclut que bien qu'un élargissement progressif de cerlaines obligations de divulgation actuelles de la défense soit indiqué, il semble que les obstacles constitutionnels à la mise en cuvre d'une pleine divulgation réciproque de la défense au Canada sont entiers et justes.

\section{TABLE OF CONTENTS}

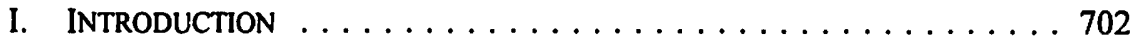

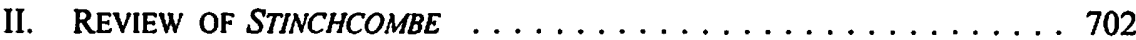

III. CONSIDERATION OF THE JUSTIFICATION OF

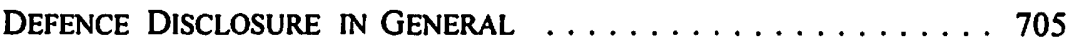

A. THE IDEA OF "RECIPROCAL" DISClOSURE

AND ITS INADEQUACIES . . . . . . . . . . . . . . 705

B. CONSTITUTIONAL ARGUMENTS Against LAWS

REQUIRING DEFENCE DISCLOSURE, IN PARTICULAR

THE RIGHT AGAINST SELF-INCRIMINATION, THE

RIGHT TO SILENCE AND THE RIGHT TO MAKE FULL

ANSWER AND DEFENCE . . . . . . . . . . . . . 709

IV. A REFLECTION ON WHAT KINDS OF DEFENCE

DISCLOSURE REQUIREMENTS COULD BE DEVELOPED

WITHIN SUCH A SYSTEM $\ldots \ldots \ldots \ldots \ldots \ldots \ldots \ldots \ldots \ldots \ldots$

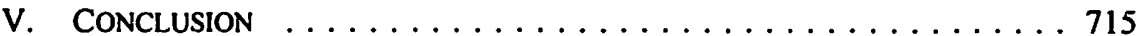

Professor, Faculty of Law, University of Calgary. The author would like to acknowledge the assistance of James Pickard, student assistant and Glen Luther, who supervised the project. 


\section{INTRODUCTION}

The purpose of this article is to examine some of the problems that stand in the way of introducing compelled defence disclosure in Canadian criminal law in light of Stinchcombe v. The Queen, ${ }^{\prime}$ and to consider what these problems tell us about the use that could be made of defence disclosure. It is my premise that the analysis arising under s. 7 of the Canadian Charter of Rights and Freedoms ${ }^{2}$ provides an excellent framework for the development of principled rules on defence disclosure. This analysis demonstrates that many of the proposals made for defence disclosure are clearly inappropriate under current Charter analysis and fundamental Canadian law, but that there exist principles that would allow the development of appropriate requirements of defence disclosure.

Many commentators have reviewed the various obligations of defence disclosure that exist in the common law world. ${ }^{3}$ It is not my intention to review those obligations. Instead, I will focus on the reasons for and against defence disclosure within the unique context of Canadian criminal and constitutional law.

The arguments in favour of defence disclosure are reasonably obvious, particularly since Stinchcombe. The Crown is obliged to reveal all relevant material to the defence, with the supposed result that the defence can prepare with a full understanding of what information the Crown has. The defence, on the other hand, may stand back, wait in the weeds, and spring things on the Crown. This has two effects. First, it enables the defence to tailor its evidence to the evidence of the Crown, rather than having to make its case before knowing what the Crown will say. Second, it puts the Crown in a position where it cannot investigate the accused's evidence or the proposed defence in advance. Both of these features appear to undermine the criminal trial as a search for truth, and make it seem more of a game - even though the stakes are very high for the accused and for society. In such circumstances, does it not make sense for the accused to be required to reveal his or her case as the Crown must? Assuming that we want to move towards introducing some general obligation of defence disclosure in Canada, let us and examine the possibilities that exist for doing so.

\section{REVIEW OF STINCHCOMBE}

The case that revived interest in disclosure was the Supreme Court's decision in Stinchcombe in 1991. The finding of the Supreme Court on the Crown obligation of disclosure and the reasons for that finding are essential to my discussion.

[1991] 3 S.C.R. 326 [hereinafter Stinchcombe].

Canadian Charter of Rights and Freedoms, Part I of the Constitution Act, 1982, being Schedule B to the Canada Act 1982 (U.K.), 1982, c. 11 [hereinafter Charter].

See, e.g., G.D. McKinnon, "Accelerating Defence Disclosure: A Time for Change" (1996) I Can. Crim. L.R. 59; S. Costom, "Disclosure by the Defence: Why Should I Tell You?" (1996) I Can. Crim. L.R. 73; M.D. Tochor \& K.D. Kilback, "Defence Disclosure: Is it Written In Stone?" (2000) 43 Crim. L.Q. 393. 
Section 7 of the Charter states: "Everybody has the right to life, liberty and security of the person and the right not to be deprived thereof except in accordance with the principles of fundamental justice." An earlier decision of the Supreme Court had found that the principles of fundamental justice included the right of the accused to make full answer and defence. ${ }^{5}$ In Stinchcombe, the Supreme Court found that nondisclosure by the Crown impedes the ability of the accused to make full answer and defence, and that there is therefore an obligation on the Crown to disclose its material to the defence. They thus elevated the right to disclosure to a constitutional status, and took it far beyond an ethical obligation or even a common law obligation.

The Court took some pains to set out the content of the obligation on the Crown to disclose, despite making it clear that the details would have to be "worked out in the context of concrete situations." It stated that

the general principle ... is that all relevant information must be disclosed subject to the reviewable discretion of the Crown. The material must include not only that which the Crown intends to introduce into evidence but also that which it does not. No distinction should be made between inculpatory and exculpatory evidence. ${ }^{7}$

Moreover, initial disclosure should occur before the accused elects his or her mode of trial or pleads to the charge, and should continue whenever additional information is received.

The "reviewable discretion" relates to a number of issues: first, whether the evidence is in fact relevant; second, whether the information is covered by privilege (for example, the privilege attaching to police informants) and whether, despite the privilege, the withholding of the information so impairs the right of the accused to make full answer and defence that the privilege must be overridden; third, whether the disclosure can be delayed due to concerns about the safety of witnesses.

For our purposes, however, I will be focusing on the Court's reasons for creating this constitutional obligation of disclosure on the Crown. The Court noted that the resistance in Canada to enacting comprehensive rules mandating Crown disclosure appeared to be based on the fact that the proposals for reform did not provide for reciprocal disclosure by the defence. ${ }^{8}$ The Court then pointed out that, while reciprocal disclosure might be something that the Court could look at in the future, it was not necessary to delay the implementation of Crown disclosure because defence disclosure was not being addressed.

Charter, supra note 2, s. 7.

Dersch v. Canada (A.G.), [1990] 2 S.C.R. 1505 at 1513-15 [hereinafter Dersch].

Stinchcombe, supra note 1 at para. 25.

lbid. at para. 29.

See, e.g., Law Reform Commission of Canada, Working Paper on Criminal Procedure: Discovery, in Study Report: Discovery in Criminal Cases (Ottawa: Information Canada, 1974) and Canada, Report on Disclosure by the Prosecution (Ottawa: Supply and Services Canada, 1984). 
The Court justified differential treatment on the basis that the Crown and the Defence have fundamentally different roles. The Crown is a representative of the state and as such has a public duty not to have "winning" (convicting) as a goal. Rather, its duty is to ensure that all available evidence is placed before the court and that the state plays fair. This may be an idealized perception of Crown prosecutors, especially within the adversarial system, but the Court's next distinction rings very true. It pointed out that the evidence the Crown has is not the property of the Crown for the purpose of securing a conviction, but the property of the public to be used to ensure that justice is done. This must be right. Even if the Crown, as adversary, is entitled to work for a conviction, the evidence does not belong only to one side, and the purpose of the investigation is not to convict the accused, but to find the truth and ensure that, to the greatest extent possible, justice is done.

The Court then looked at the reasons raised against a Crown obligation to provide full disclosure. The first was that it would impose onerous new obligations on the Crown; in answer, the Court pointed out that in many cases the Crown already provided full disclosure voluntarily and the time required for disclosure was already taken into account. Moreover, it would avoid appeals such as the one in Stinchcombe itself, and avoid adjournments and other manoeuvres because defence counsel had no opportunity to prepare for the evidence presented.

The second argument against the imposition of a disclosure obligation on the Crown was that it would allow the defence to tailor its evidence to meet the evidence presented by the Crown. The Court found that allowing the Crown to take the defence by surprise is not part of the justice system:

This may rob the cross-examiner of a substantial advantage but fairness to the witness may require that a trap not be laid by allowing the witness to testify without the benefit of seeing contradictory writings which the prosecutor holds close to the vest. The principle has been accepted that the search for truth is advanced rather than retarded by disclosure of all relevant material. ${ }^{9}$

Finally, the Court dealt with the security issue - the concern that the safety of witnesses may be jeopardized by disclosure of their names and their statements, and that revealing the identity of police informants would jeopardize other investigations. The Court recognized that these important considerations need some protection. However, it found that they must give way to the right of the accused to make full answer and defence when that is the issue, and that the issue will be not so much whether to disclose as when to disclose. Disclosure may be delayed for these reasons, but it will not be denied entirely.

My purpose is to use these aspects of Stinchcombe as a framework for a discussion of defence disclosure. Stinchcombe is the strongest and most persuasive statement we have in Canada on criminal law discovery. Thus, it sets the stage for all further discussions of discovery, including discovery of defence information. 


\section{CONSIDERATION OF THE JUSTIFICATION OF DEFENCE Disclosure in General}

\section{A. THE IDEA OF "RECIPROCAL" Disclosure AND ITS INADEQUACIES}

One of the most confusing things about the discussion of discovery in criminal law is the use of the term "reciprocal disclosure" to refer to defence disclosure. Reciprocity includes a sense of equivalency or correspondence. There are many reasons why there cannot be true reciprocal disclosure by the defence. However, the fact that there cannot be reciprocal disclosure does not necessarily mean that there cannot be any mandatory disclosure by the defence. Therefore, referring to defence disclosure as "reciprocal disclosure" can muddy the waters unnecessarily.

In the Canadian context, and particularly in light of Stinchcombe, the Crown disclosure obligation is a constitutional obligation. It was developed by the Supreme Court of Canada in Stinchcombe without any common law basis or statutory authority. Therefore, the Supreme Court's statement in Stinchcombe - "The suggestion that the duty should be reciprocal may deserve consideration by this court in the future but is not a valid reason for absolving the Crown of its duty"10 — is puzzling; under what rubric of the Charter could a disclosure requirement on the defence possibly be found?

There are no independent defence obligations under the Charter. The Charter is aimed at governmental action, and the defence, unlike the Crown, is not part of government. Moreover, the only way that a liberty or security interest could be affected by the actions of the defence is by arguing that a complainant or a future victim loses some of his or her security when a guilty accused is acquitted and released. But even to the extent that such a security interest exists, the only way to find that government action has deprived the members of society of their security would be by finding that the processes orchestrated by the government in criminal trials have allowed the accused to use the system to gain his or her freedom. Also, it would require a finding that the failure to require defence disclosure was the element that allowed the guilty accused to go free. However, even that would not be enough; to meet the requirements of $s$. 7 of the Charter, the failure to require defence disclosure would have to be contrary to fundamental justice. The argument is a tortuous one, and one that would open the door to a whole different approach to s. 7. Every issue would become one requiring a balancing of the accused's rights and the right of future victims. It would change the very nature of the Charter, and the very nature of criminal law. There has been no indication in s. 7 analysis that security interests will be given such a broad reading, or that government responsibility will be found to extend to the conduct of the defence, and every reason to expect that they will not. Therefore, if the Court were able to find that the Crown disclosure requirement in Stinchcombe was not based on any reciprocal obligation of defence disclosure, it is hard to see that there exists any realistic method of creating an obligation of defence disclosure through the Charter. 
That there is such a fundamental distinction between the Crown's position and the defence's position can be seen by considering the principle of fundamental justice applied in Stinchcombe: it was the right of the accused to make full answer and defence. There is no principle of fundamental justice that gives the Crown the right to make "full" prosecution and requires that the defence assist in that process. Stating it in this way demonstrates how inconsistent it is with the whole history of criminal law in Canada. The only circumstances in which the courts have found that the wellestablished rights of the defence to make full answer and defence must be balanced with the interests of another party are when that other party has an independent right under the Charter: for instance, a right of equality or privacy. "Moreover, in each of these cases, the Court was asked not to create new law under the Charter, but to find that new law created by Parliament was not inconsistent with the Charter. It is hard to find any support for the idea that a new obligation on the defence could be created by pure Charter application, such as the new obligation on the Crown created in Stinchcombe.

It is also hard to see how the Court could create such an obligation as a reciprocal duty to the Crown's duty under s. 7. The idea that the government has such an obligation only if the defence reciprocates does not fit well with the concept of fundamental justice affecting the liberty interests of the accused. In my opinion, there is no way that any kind of reciprocal duty can be imposed on the defence through Charter analysis.

Can the courts create the duty through the common law? It is possible for them to create specific duties, such as the one that exists for alibi evidence, and there may be developments in that direction. However, it is currently difficult to see any basis for creating a broad new rule of defence disclosure. None has existed in England or Canada. The only thing that has changed recently in Canada is that the Charter has allowed the courts to create a constitutional obligation on the Crown. However, to read that as allowing the Courts to create a common law obligation on the defence would be to allow the courts to take a "tit for tat" approach to the constitution, that is, creating a common law duty on the defence to balance the constitutional duty on the Crown. But constitutional duties are different in kind from common law duties; they are based on the government's obligation to its people as spelled out in a constitutional document. There is no basis for using this document, or the obligations it places on the government, to suggest that there should be concomitantly more obligations on the people. Yet that is arguably what creating a broadly-based common law defence disclosure obligation after Stinchcombe would be. Furthermore, the Supreme Court has acknowledged that changes to long-standing common law rules should be incremental complainants by the defence in the trials of sexual offences, and all three cases balanced the interest of the accused in making full answer and defence with the complainant's privacy and equality rights. 
in nature; that is not only in accordance with the common law process, but also avoids usurping the proper function of the legislature. ${ }^{12}$

The position that there cannot be a reciprocal defence duty of disclosure finds further support when one considers in detail what the obligation created by Stinchcombe is. Remember what the Court said:

\begin{abstract}
the general principle ... is that all relevant information must be disclosed subject to the reviewable discretion of the Crown. The material must include not only that which the Crown intends to introduce into evidence but also that which it does not. No distinction should be made between inculpatory and exculpatory evidence. ${ }^{13}$
\end{abstract}

The focus is on information collected by the Crown (or information, in certain circumstances, that could be collected by the Crown). A truly reciprocal obligation on the defence would mean that the defence must provide all the information it has collected to the Crown. But none of the reasons that apply to the Crown apply to the accused. The Crown is a public servant, as are the police; they are collecting information for the public good. The accused and his or her defence counsel are not public servants; they are not collecting information for the public good. On what theory is that information the information of all? While defence lawyers are officers of the Court and their ethical obligations forbid them from hiding physical evidence,,$^{14}$ they are not required to produce it in a way that incriminates their client, ${ }^{15}$ and any discussions between the lawyer and the client are privileged. The system has recognized the right of the accused and, to a large extent, defence counsel, to look after the accused's own interests in preparing for trial without much consideration for the interests of society.

Furthermore, any defence evidence that they are not planning to present at trial because the evidence is incriminating could fall under the right against selfincrimination, a principle of fundamental justice under s. 7 of the Charter. As soon as the evidence is compelled from the accused, whether it happens at trial or in pretrial procedures, it seems to raise all of the concerns associated with self-incrimination; moreover, it contains none of the balancing factors that have allowed the courts to permit some compulsion in limited circumstances where there are limited consequences for the accused, as when a person is required to make a report regarding a traffic accident. ${ }^{16}$

$12 \quad$ R. v. Hawkins, [1996] 3 S.C.R. 1043.

13 Dersch, supra note 5.

it R. v. Murray (2000), 48 O.R. (3d) 544 (Ont. Sup. Ct. J.).

is Ibid. at para. 123, where the Court suggests that the material in question could be turned over anonymously; see also G. MacKenzie, Lawyers and Ethics: Professional Responsibility and Discipline, 2d ed. (Toronto: Thomson Canada, 1999) at 7.8-7.9.

16 This requirement is found in provincial legislation governing motor vehicle administration: see, e.g., in Alberta, Motor Vehicle Administration Act, R.S.A. 2000, c. M-23, s. 77(1); and in British Columbia, Motor Vehicle Act, R.S.B.C. 1979, c. 288, s. 61(1) [am. 1986, c. 19, s. 2; 1990, c. 71, s. 7]. These are normally accompanied by the use of immunity provisions: in Alberta, Motor Vehicle Administration Acl, R.S.A. 2000, c. M-23, s. 81(2); and in British Columbia, Motor 
In fact, none of the provisions or the suggested provisions for defence disclosure that I have reviewed require the defence to share all information. The most they require is that the defence share the information that it is actually going to present at trial. This makes it clear that the kind of defence disclosure obligation at issue is based on a totally different purpose from the Crown obligation set out in Stinchcombe. Stinchcombe is based on the idea that the defence should know all of the information, not only the information in the Crown's case. It stems to a large extent from cases in which the Crown had information that it did not use that would have been advantageous to the accused (as in the Donald Marshall case). ${ }^{17}$ It is based on the idea of a public responsibility and a sharing of public information by both parties to the adversarial process.

The idea of defence disclosure, however, is based on the need to prepare to refute the accused's case. It has nothing to do with the sense that the defence has a public responsibility to collect information for both parties to use. Once this distinction is grasped, it is possible to see another problem with the reciprocity suggestion. Nothing in Stinchcombe even requires the Crown to reveal its case, although it will often do so as a consequence of revealing the information. Nevertheless, to require the defence to reveal its case is in fact imposing a different and in some ways more onerous obligation. If the defence is to be obligated to reveal its case, it would seem fair to include this obligation in the Crown's set of disclosure responsibilities as well, and that would be adding a new disclosure obligation.

The fundamental point to recognize is that reciprocal disclosure is not actually reciprocal, but rather based on a different sense of obligation than that recognized by the Supreme Court in Stinchcombe. Thus, the argument can be made that Stinchcombe has not changed the legal landscape in regard to defence disclosure at all.

While recognizing that there appears to be a basis for neither a constitutional nor a common law development of defence disclosure as a general principle, it would still be possible to enact legislation that brings a scheme of defence disclosure into the criminal law. There are thus two possible ways to bring defence disclosure into criminal law. The first is through an incremental common law approach building on such current developments as the requirement to supply notice of intent to use the alibi evidence. The second is through statute.

Vehicle Act, R.S.B.C. 1979, c. 288, s. 61(7) [am. 1986, c. 19, s. 2]. In R. v. White, [1999] 2 S.C.R. 417, the Supreme Court held (L'Heureux-Dube J. dissenting) that statements made under the British Columbia requirement were not admissible in criminal proceedings against the maker of the statements, because it was only if immunity were granted in that forum as well as in the provincial forum that the principle against self-incrimination as it existed under 5.7 was not infringed. There is still a serious issue whether provisions such as the one found in Alberta are consistent with the Charter, since the immunity provided in Alberta is not complete but does allow the statement to be used for the purpose of establishing who was driving the vehicle at the time of the accident.

17 See the discussion in Stinchcombe, supra note 1 at 335-36. 
In order to deal with the possibility of legislation in the area, we must consider whether such legislation would be subject to constitutional attack. Moreover, any analysis that suggested that such legislation would be unconstitutional would equally suggest that a common law development of the same sort would be unconstitutional.

\section{B. Constitutional ARguments Against Laws ReQuiring Defence disclosure, in Particular the Right against SELF-INCRIMINATION, THE RIGHT TO SILENCE AND THE Right TO MAKe Full ANSWER AND DEFENCE}

The main constitutional arguments that can be mounted against legislative requirements of defence disclosure are the right to silence, the right against selfincrimination and the right of the accused to make full answer and defence, including the underlying principle that the Crown has to present a case to meet before any obligation arises for the accused to say or do anything. These are fundamental tenets of the criminal justice system in Canada. Yet, it is safe to say, none of these elements is so clearly defined that it cannot be challenged.

As mentioned above, the right against self-incrimination under s. 7 of the Charter appears to be the strongest argument against requiring the accused to disclose evidence that the defence is not planning to use. Since this does not seem to be the focus of most of the efforts to compel defence disclosure, I do not intend to spend more time on that constitutional right.

The right that seems most relevant to the idea compelling the defence to disclose their case or the evidence they will rely on before trial is the right to silence, or the right of an accused not to speak and therefore not to suffer any authorized sanctions for not speaking. This is considered a fundamental principle of justice and therefore an element in s. 7 of the Charter, as noted in $R$. v. Herbert. ${ }^{18}$ The argument has been made by Brian Maude, however, that Hebert applies the right to silence only to detained persons and that therefore it would not apply to considerations of disclosure. ${ }^{19}$ On the contrary, it could be recognized that what Hebert was considering was the use of the right to silence in an unusual sense. The question was whether a trick by the authorities, causing the accused to speak while in detention, contravened his right to silence. Thus, it was designed to deal with a situation that did not appear to be silence at all; in fact, the accused had chosen to speak, and without any threats or inducements from the Crown. What the Court was doing in that case, therefore, was bringing a new situation within the ambit of the right to silence. It wanted to limit the extended application of the right and therefore held that the extension would apply only in detention situations. It did not suggest that the right to silence in its full constitutional sense was limited to detention situations.

18 [1990] 2 S.C.R. 151 [hereinafter Hebert].

19 B. Maude, "Reciprocal Disclosure in Criminal Trials: Stacking the Deck Against the Accused, or Calling Defence Counsel's Bluff?" (1999) 37 Alta. L. Rev. 715. 
There is thus a strong argument that requiring the accused to reveal anything (whether their own information or information they have collected) prior to the time the defence presents its case at trial is offensive to the right to silence. If this is the case, then any requirement of defence disclosure contravenes the right to silence and s. 7 of the Charter, and would be struck down unless s. 1 could be invoked to save it. The arguments that I have made above would indicate that it would normally be very difficult to successfully argue s. 1 and, as noted below, there is no history of the Supreme Court using s. 1 in this way.

There is nevertheless some room for movement here. There does exist a common law requirement that the defence reveal an alibi defence in sufficient time and detail to allow the Crown to investigate whether the alibi is a fabrication. This obligation impinges on the accused's right to silence. That has led the courts to require only minimal elements in the disclosure of the alibi, and also to limit the consequences of not disclosing the alibi. The current rule is that the alibi must be revealed in sufficient time and detail to allow the Crown to investigate, not that it must be revealed at the earliest possible opportunity. ${ }^{20}$ It has been held that a requirement that it be revealed at the earliest possible moment would clearly contravene the right to silence. ${ }^{21}$ Moreover, the consequence of not revealing the alibi is not that evidence about it is inadmissible; instead, the failure to give notice can lead only to the weakening of the evidence. For example, the jury can be instructed that the alibi evidence is weaker than it would be if it had been revealed in a timely manner. According to my research, there has never been a careful Charter analysis of this requirement. It is, for instance, unclear whether it survives because it does not contravene s. 7 or because it is saved by s. 1 , although Sopinka J. for the majority in $R$. v. Noble $e^{22}$ indicates - without extensive analysis - that it has been incorporated into s. $7 .{ }^{23}$ In many ways, the use of s. 1 may make more sense, but the Courts have not applied the Oakes ${ }^{24}$ test in their discussions, and therefore it seems to have been accepted as appropriate under s. 7 despite the fact that the Courts have said that it contravenes the right to silence.

Thus, there is at least one clear pretrial requirement of defence disclosure accepted by the Courts, although it has been limited. The question is whether that acceptance opens a hole in the right to silence through which other defence disclosure obligations could be driven.

It is important to note that the Courts have distinguished alibi evidence from other evidence and have not been willing to extend the obligation to other circumstances. The distinguishing features were discussed in Cleghorn. In that case, the issue was whether adequate advance disclosure of an alibi had been given by the accused's mother. The majority and dissent disagreed on the application of the test to the facts in the case, but agreed on the test and also on the background of the special requirements in alibi

Cleghorn v. The Queen, [1995] 3 S.C.R. 175 [hereinafter Cleghorn].

R. v. Parrington (1985), 9 O.A.C. 76; R. v. Taillefer (1989), 26 Q.A.C. 246.

[1997] I S.C.R. 874.

Ibid. at para. 75.

R. v. Oakes, [1986] I S.C.R. 103. 
evidence. The special concern with alibi evidence is that it can be more easily fabricated than other evidence because it is not connected with the main factual issue and therefore with the other evidence the Crown has collected. There is no need for the accused to fit the alibi with the other evidence; it is totally separate and the Crown usually has no reason to suspect it exists until the accused raises it. This makes that evidence particularly difficult to deal with, and therefore deserving of special attention - that is, advance disclosure. However, note that even in this special case the requirements of disclosure are minimal and the consequences only a matter of weakening the evidence, not excluding it.

The Supreme Court has had the opportunity to extend the requirements of defence disclosure to similar situations and has refused to do so. In $R$. v. Chambers, ${ }^{25}$ the Court was dealing with questions to the accused in cross-examination. The accused had testified that he was not part of the conspiracy to import cocaine with which he was charged and instead only went along for other purposes (he was a lawyer and claimed he had been led by his heart) and that he had hired someone to go the States and rob the co-conspirators of the cocaine to prevent its ever being imported into Canada. The cross-examination suggested that this was the first time he had mentioned this defence and that it was a recent concoction. The Supreme Court held that the failure of the trial judge to instruct the jury specifically that the accused had the right to silence and therefore had no obligation to reveal this evidence in advance was an error requiring a new trial. They specifically stated that the requirement to disclose an alibi was a unique situation, and continued:

As a general rule there is no obligation resting upon an accused person to disclose either the defence which will be presented or the details of that defence before the Crown has completed its case. There was clearly no obligation resting upon the appellant to disclose either his defence of double intent or the Kuko story to the Crown or anyone in authority. The failure to correct such an impression by direction from the trial judge rendered the right to silence a snare of silence for the appellant. ${ }^{26}$

This suggests that it will in fact be very difficult to enact a piece of legislation to require defence disclosure that does not run afoul of the right to silence. It would be necessary that it not allow for a "snare of silence" and that there be no other reasonable method by which the Crown could prepare for the defence. It certainly seems that there is little room for the general kind of defence disclosure provision envisioned by most who deal with this subject.

It also suggests that the best way to proceed with disclosure requirements on the defence is to allow the development of the common law in the area or to enact very limited defence disclosure obligations that meet the above requirements. The defence would have to be separate from the facts of the case and there could be no other method by which the Crown could get the evidence necessary to prepare its case. As an example of other methods, there has been legislative activity to solve this kind of problem in relation to the insanity defence, which, like an alibi, is separate from the 
main facts of the case and may come as a surprise to the Crown. However, this is not handled by a requirement of advance disclosure. Instead, once the accused raises the issue, the Crown has the right to apply for an assessment to be done that can be used in the trial itself and in the disposition. In other words, this kind of problem has been handled without requiring any pretrial disclosure. However, it is important to note that it would not be expedient to use this method in other situations due to the fact that it requires that the trial be stopped until the assessment is complete. In this case, given the nature of the investigation that must be done (in particular that it requires the accused's own participation), that seems the appropriate balance. However, this is not required in an alibi disclosure, where expediency suggests that it is better to require the defence to disclose the alibi in advance. Thus, the right to silence stands as a barrier that any legislation would have to scale, and one with which common law developments would have to deal.

The final constitutional barrier to mention in this context is the one that started this inquiry: the right of the accused to make full answer and defence. In this case, many of the concerns are similar to those I have raised in relation to the right to silence. However, this does give me an opportunity to address one of the most difficult aspects of dealing with defence disclosure, that is, what penalty can be used for a failure to comply. At the moment, the Crown has the right to ask for an adjournment when evidence that comes as a surprise could not have been anticipated, and is very likely to succeed. Therefore, it is not necessary to create rights of disclosure to garner that remedy to allow the Crown to investigate the claim and prepare for cross-examination.

However, any other remedy would seem contrary to the right of the accused to make full answer and defence. Given that there is no similar Crown right (to full prosecution) and therefore nothing to foreshorten the accused's right, it would seem that anything that weakens the ability of the accused to give full answer and defence must be considered contrary to $\mathbf{s .} 7$ of the Charter. Requirements that undermine the accused's right to put the Crown to its proof before presenting its own case would prima facie seem to weaken the defence's right to make full answer and defence. In $R$. v. Rose, ${ }^{27}$ the Supreme Court held that the accused had the right to see the Crown's full "case to meet" before being required to answer by adducing evidence, as well as the right to defend him or herself. If the defence must disclose its case or its evidence before that time (even though it is not actually adducing the evidence before that time) and can suffer consequences relating to such things as the strength of the evidence if it does not do so, then it is in a position where it must effectively adduce evidence before the Crown has provided the case to meet.

There have been some developments that need to be considered when evaluating the strength of the right granted to the accused to make full answer and defence in this context. For instance, in the cases of $R$. v. $L a^{28}$ and $R$. v. Dixon ${ }^{29}$ the Supreme Court held that lack of disclosure on the part of the Crown will provide the accused with a 
s. 7 argument only if there is a reasonable possibility that the undisclosed evidence would have affected the accused's ability to make full answer and defence; when the evidence has been lost without the negligence of the police or Crown, the accused must establish actual prejudice. While some may argue that these cases weaken the right to full answer and defence, it is more likely that they weaken only the obligation of disclosure on the Crown, that is, that disclosure is not required unless it can be actually shown to assist the accused in making his or her constitutionally guaranteed full answer and defence. If that is so, they would equally weaken the reason for requiring disclosure from the defence, and thus these cases do not support a requirement of defence disclosure.

It is also important to recognize that the decisions in cases like Cleghorn, which are stringent in determining what amounts to adequate notice (the majority holding that the mother had not given adequate notice because the timing was not perfectly clear), will not encourage the courts to require notice or defence disclosure. If the requirements are rigidly applied, such notice requirements have far more potential for affecting an accused's right to full answer and defence than if they incorporate more flexibility.

\section{A Reflection on What Kinds of Defence Disclosure Requirements Could Be Developed Within Such a System}

If it is impossible to develop a system of defence disclosure under the guidelines that have been set down by the Supreme Court of Canada in interpreting the Charter, is there any possible movement that can be made in this area? It needs to be acknowledged that there are obligations of defence disclosure that exist and that do not appear to contravene the Charter. The requirement of notice of an alibi has already been mentioned. In addition, there are obligations when an accused is planning to make a Charter challenge,$^{30}$ particularly a challenge to legislation. It can be understood that this kind of challenge, like an alibi, is unrelated to the main issue at trial, and therefore something that a well-prepared Crown might not anticipate. Furthermore, these kinds of challenges raise issues that affect far more than the case at hand; when the challenge is to the validity of legislation in particular, the issues affect everyone. Therefore, there are particular concerns that must be balanced against the right of the accused to make full answer and defence.

In addition, there are obligations under ss. 276-276.5 of the Criminal Code ${ }^{31}$ for the defence in a case involving a sexual offence to give notice if they intend to adduce evidence of sexual activity of a victim unrelated to the charge. Moreover, the defence must establish the relevance of the evidence through a voir dire, which will require the defence to reveal its defence strategy. This scheme has been found not to contravene the right to silence because it is not a pretrial procedure and because the accused has the choice of whether to try to introduce the evidence in the first place; therefore, whether the accused must make any prior disclosure is within the accused's control. ${ }^{32}$ 
It should be noted, however, that this argument could be made with regard to almost any defence evidence, and therefore it would most likely not have been enough on its own to uphold the constitutionality of the provisions. However, there was an additional basis for allowing the procedure, and it was arguably the most important. The nature of the evidence that the accused wished to introduce meant that other Charter interests were involved - in particular the equality and privacy interests of the complainant. The Supreme Court found that the privacy and equality rights of the victim must be balanced with the right of the accused to make full answer and defence, and that the requirements of notice and providing a basis for finding relevance does not so seriously affect the accused's ability to make full answer and defence that it overrides the other interests.

The case of $R$. v. Underwood ${ }^{33}$ demonstrates another situation in which the defence must reveal the evidence that it intends to call before it actually calls the evidence. It involved a Corbet ${ }^{34}$ application, asking that the criminal record of the accused be excluded due to the fact that its probative value was outweighed by its prejudicial effect. The defence made the application at the close of the Crown's case, with the intent that the accused would testify if the application were granted. The trial judge deferred consideration of the application until after the accused's testimony, since one of the determining factors was the nature of the defence evidence. Given that, the accused did not testify and was convicted. The Supreme Court held that it was unfair to the accused to make him decide whether to testify without knowing in advance whether his criminal record could be introduced. However, the trial judge was right that the nature of the defence evidence was a relevant factor in the determination. The way around this dilemma was to hold a voir dire in which the defence would reveal the evidence it would be calling. The judge would then rule on the basis of what was said at the voir dire. The accused would not be bound by what was said at the voir dire but if the evidence deviated from that indicated, the judge would be able to change the ruling on the Corbett application. In this case, then, some kind of defence disclosure was required for an appropriate ruling on the law (similar to the s. 276 situation). Here, the additional factor was not the other rights of the complainant, but rather the fact that the accused was choosing to request the exercise of a discretion that required the information. Again, there was an additional factor that made the disclosure necessary in the particular circumstances.

Thus, it is clear that in dealing with that myriad of rights that exist within s. 7 of the Charter and in balancing the rights as between s. 7 and other Charter sections, the courts do not and cannot view the right to make full answer and defence as an absolute. It must be viewed with clear vision, and it is possible that where the impingement on the right is minor while the needs of another right are strong, the right to make full answer and defence will give way. However, it is important to recognize that this has normally happened only when the concern is the protection of another right, such as privacy or equality, the validity of legislation, or when the issues in question are far removed from the central issue at trial (and even then only when the right to make full 
answer and defence is not seriously impaired, such as when the disclosure takes place during trial, and is not required prior to trial). When there is nothing to balance or the need of the accused is strong, the right to make full answer and defence is still quite robust, if not absolute.

\section{Conclusion}

It has been my position in this article that there is a fundamental worm at the heart of the apparently appetizing apple of defence disclosure. I would contend that the very existence of cases like Stinchcombe will make it impossible at the end of the day for anything approaching reciprocal disclosure to develop in Canadian law. The most that could be accomplished is an expansion of the alibi requirement either at common law or by statutory reform. When one examines the whole picture that has been painted by s. 7 analysis, it is clear that such a limitation is appropriate for justice, not contrary to it. Within the criminal justice system there are many examples of gentle encouragement to disclose elements of the defence case. That is as it should be, and it is appropriate for the system that the Crown and the defence make use of them. However, the step from that to mandatory disclosure is a leap that would undermine many of the principles fashioned by the Charter. It is not necessary and, under current Charter analysis, it would not be right. 